\title{
Detection of Antimicrobial Residues in Poultry Litter: Monitoring a Risk through a Selective and Sensitive HPLC-MS/MS Method
}

 \\ Betty San Martín ${ }^{3}$, Aldo Maddaleno ${ }^{2,3}{ }^{,}$Héctor Hidalgo ${ }^{4}$ and Javiera Cornejo ${ }^{1, *(1)}$ \\ 1 Department of Preventive Animal Medicine, Faculty of Veterinary and Animal Sciences, University of Chile, \\ Santiago 8820808, Chile; kariyevenescoa@gmail.com (K.Y.); katiavalerievna@ug.uchile.cl (E.P.); \\ lina.trincado@ug.uchile.cl (L.T.); llapierre@uchile.cl (L.L.); ngalarce@ug.uchile.cl (N.G.) \\ 2 Programa de Doctorado en Ciencias Silvoagropecuarias y Veterinarias, Campus Sur Universidad de Chile, \\ Santiago 8820808, Chile; amaddaleno@veterinaria.uchile.cl \\ 3 Laboratory of Veterinary Pharmacology (FARMAVET), Faculty of Veterinary and Animal Sciences, \\ University of Chile, Santiago 8820808, Chile; bsmartin@uchile.cl \\ 4 Laboratory of Avian Pathology, Faculty of Veterinary and Animal Sciences, University of Chile, \\ Santiago 8820808, Chile; hhidalgo@uchile.cl \\ * Correspondence: jacornej@uchile.cl; Tel.: +56-2-2978-5630
}

\section{check for} updates

Citation: Yévenes, K.; Pokrant, E.; Trincado, L.; Lapierre, L.; Galarce, N.; Martín, B.S.; Maddaleno, A.; Hidalgo, H.; Cornejo, J. Detection of Antimicrobial Residues in Poultry Litter: Monitoring a Risk through a Selective and Sensitive HPLC-MS/MS Method. Animals 2021, 11, 1399. https://doi.org/ 10.3390/ani11051399

Academic Editor: Giuseppe Maiorano

Received: 31 March 2021

Accepted: 19 April 2021

Published: 14 May 2021

Publisher's Note: MDPI stays neutral with regard to jurisdictional claims in published maps and institutional affiliations.

Copyright: (c) 2021 by the authors Licensee MDPI, Basel, Switzerland. This article is an open access article distributed under the terms and conditions of the Creative Commons Attribution (CC BY) license (https:// creativecommons.org/licenses/by/ $4.0 /)$.
Simple Summary: After administration of antimicrobials, poultry excrete significant concentrations of antimicrobials through their droppings, which accumulate in the litter where poultry are housed. Poultry litter, which consists mainly of wood shavings, feathers, and droppings, is widely used as an agricultural fertilizer worldwide. The period that antimicrobials persist in agricultural soils could present various environmental and public health concerns. Thus, in this research, a method to identify different families of antimicrobials in poultry litter was developed. Results show that HPLC-MS/MS can reliably detect nine different compounds from three families of antimicrobials. This method was used to identify antimicrobials from commercial poultry flocks, providing a valuable and specific tool to monitor these residues in poultry litter prior to its use as an agricultural fertilizer.

Abstract: Tetracyclines, sulphonamides, and quinolones are families of antimicrobials (AMs) widely used in the poultry industry and can excrete up to $90 \%$ of AMs administrated, which accumulate in poultry litter. Worryingly, poultry litter is widely used as an agriculture fertilizer, contributing to the spread AMs residues in the environment. The aim of this research was to develop a method that could simultaneously identify and quantify three AMs families in poultry litter by high-performance liquid chromatography-tandem mass spectrometry (HPLC-MS/MS). Samples of AMs free poultry litter were used to validate the method according to 657/2002/EC and VICH GL49. Results indicate that limit of detection (LOD) ranged from 8.95 to $20.86 \mu \mathrm{g} \mathrm{kg}-1$, while limits of quantitation (LOQ) values were between 26.85 and $62.58 \mu \mathrm{g} \mathrm{kg}^{-1}$ of tetracycline, 4-epi-tetracycline, oxytetracycline, 4-epi-oxytetracycline, enrofloxacin, ciprofloxacin, flumequine, sulfachloropyridazine, and sulfadiazine. Recoveries obtained ranged from 93 to $108 \%$. The analysis of field samples obtained from seven commercial poultry flocks confirmed the adequacy of the method since it detected means concentrations ranging from 20 to $10,364 \mu \mathrm{g} \mathrm{kg}{ }^{-1}$. This provides us an accurate and reliable tool to monitor AMs residues in poultry litter and control its use as agricultural fertilizer.

Keywords: antimicrobials; poultry litter; agriculture fertilizer; HPLC-MS/MS; validation

\section{Introduction}

The use of antimicrobials (AMs) in poultry production dates to the 1940s when it became an essential tool in the development of the poultry industry. AM administration was essential because infectious diseases of bacterial origin in broiler flocks can account for $20 \%$ of gross production value losses [1]. AM use has become significant with more 
than three million kilograms of AMs used in the poultry industry in the United States in 2016 [2]. Moreover, it is estimated that the global annual average consumption of AMs by poultry is $148 \mathrm{mg} \mathrm{kg}^{-1}$ [3]. Tetracyclines, sulphonamides, and quinolones are one of the AMs administered to poultry flocks [4,5]. Additionally, in Chile, there are pharmaceutical formulations of these AMs register for use in poultry production [6,7].

Poultry can excrete between 45 and $96 \%$ of AMs through their droppings as active metabolites or in their original form [8,9]. The AMs excreted accumulate in poultry litter, the principal by-product of the poultry industry. Poultry litter is a heterogeneous compound, consisting mainly of poultry droppings, litter material (e.g., wood shavings), dead skin, food debris, water, microbiota, and poultry feathers [10-12]. Moreover, concentrations reaching $2947 \mu \mathrm{g} \mathrm{kg}^{-1}$ of sulfachloropyridazine and oxytetracycline have been detected on poultry feathers, further contributing to the accumulation of AMs in litter [13,14]. Several families of AMs have already been identified in poultry litter in concentrations ranging from 0.01 to $152 \mathrm{mg} \mathrm{kg}^{-1}$ [15-17]. Moreover, currently, there are no regulations concerning the tolerance limits for residues of AMs in by-products generated by the animal industry, and the maximum residue limits (MRL) are only applicable to edible animal tissues [18].

The main problem is that poultry litter containing AM residues is widely used by farmers around the world as agricultural fertilizer. For centuries, litter has been applied to land to increase crop yield, due to the presence of nitrogen, phosphorus, and potassium [19-22]. This practice has been described as one of the main pathways by which AMs enter the environment $[4,21,23]$. In this context, Zhang et al. [24] identified more than $15 \mathrm{AMs}$, in concentrations ranging from 0.1 to $333.5 \mathrm{\mu g} \mathrm{kg}^{-1}$ in agricultural soils that were consistently amended with broiler poultry manure. Similarly, Wei et al. [25] analyzed 27 soil samples fertilized with broiler poultry droppings and detected concentration of tetracycline, quinolones, and sulphonamides up to $30,779,5305$, and $1316 \mu \mathrm{g} \mathrm{kg}{ }^{-1}$ of soil analyzed, respectively. Hou et al. [26] conducted similar research in northern China, where tetracyclines, chlortetracycline, oxytetracycline, and doxycycline were the AMs detected at higher concentrations. The use of fertilizer obtained from farm animal feces, specifically poultry litter, contributes to the dissemination of AMs into the environment.

The AMs in agricultural soil can persist for days to years [27] and bioaccumulate in cultivated vegetables [28] or migrate as a result of runoff toward new water bodies [29]. The presence of AMs in soil, water, and vegetables may have an adverse effect on human health, such as hypersensitivity, toxicity, and disruption of the gut microbiota [30-33] and contribute to the development of antimicrobial resistance [34]. Therefore, the presence of AM residues in the environment needs to be evaluated in-depth [35].

Previous works demonstrate the importance of efficiently and effectively identifying AMs in poultry litter. Multiple AMs have been identified by high-performance liquid chromatography-tandem mass spectrometry (HPLC-MS/MS) in matrices other than poultry litter [36-38]. Nevertheless, methods for poultry litter are limited [15] because the physical and chemical properties of both the poultry litter and various AMs adds to the complexity of the method. The aim of this research was to develop a specific method able to detect and quantify different families of AMs (tetracyclines, sulphonamides, and quinolones) and their main active metabolites in poultry litter. Analysis prior to its use as an agricultural fertilizer could help to prevent environmental contamination and the resulting risks for public health.

\section{Materials and Methods}

\subsection{Sample Collection}

Poultry litter was obtained from broiler chicken, genetic line Ross ${ }^{\circledR} 308$ (Aviagen Inc., Huntsville, AL, USA). Animals were not treated with AMs and managed following the recommendations described in the "Poultry Industry Manual of the United States Department of Agriculture" to simulate production farming [39]. Per $1.5 \mathrm{~m}^{2}$ of pen, 10 animals were placed on a smooth floor with $10 \mathrm{~cm}$ of wood shavings. Water, food, and wood shavings 
present in the litter were analyzed prior to exposure to birds by HPLC-MS/MS to ensure no presence of AM residues.

Poultry breeding was performed in compliance with Chilean Law No. 20,380 “On the protection of animals " [40] and the Institutional Committee for the Care and Use of Animals (CICUA, as per initials in Spanish) of the University of Chile issued a certificate (permit code 18187-VET-UCH-E1). Furthermore, the Directive 2010/63/EU “On the protection of animals used for scientific purposes" [41] and the Regulation (CE) No. 1099/2009) "On the protection of animals at the time of slaughter" were respected [42].

After 42 days of rearing, poultry litter was collected, consisting mainly of droppings, feathers, food, feed scraps, and bedding material, stored in plastic bags, and placed in a freezer at $-20{ }^{\circ} \mathrm{C}$ until it was used as a matrix spiked with $\mathrm{AM}$ residues and analyzed by HPLC-MS/MS (Figure 1).

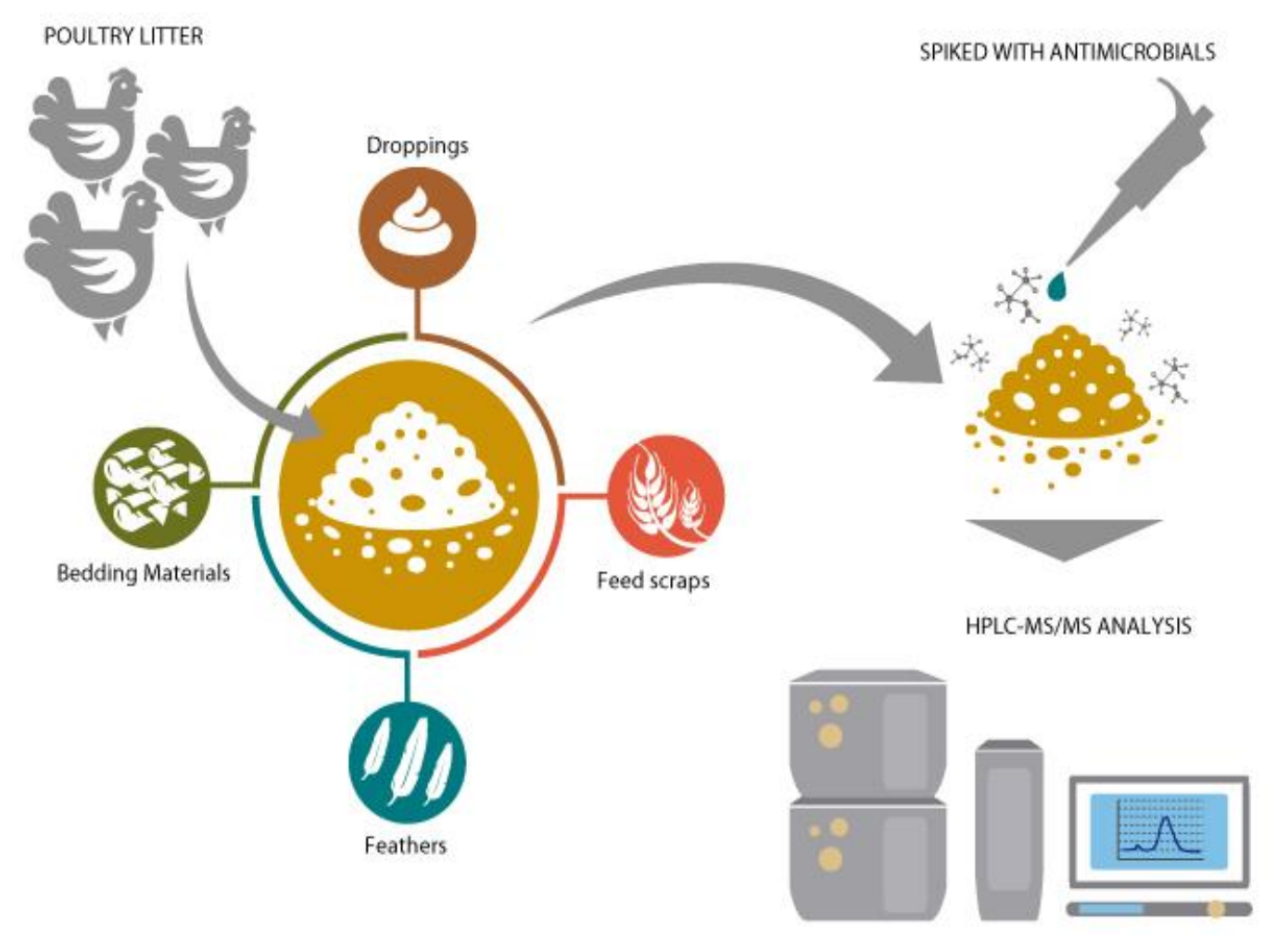

Figure 1. Production, spiked, and analysis of poultry litter.

\subsection{Standard, Reagents, and Chemicals}

Tetracycline (TC), 4-epi-tetracycline (4-epi-TC), oxytetracycline (OTC), 4-epi-oxytetracycline (4-epi-OTC), enrofloxacin (EFX), ciprofloxacin (CFX), flumequine (FLU), sulfachloropyridazine (SCP), and sulfadiazine (SDZ) with certified purity $(>90 \%)$ were manufactured by Sigma Aldrich, Inc. (Merck KGaA, Darmstadt, Germany). The internal standard (I.S.) enrrofloxacin-D5 (EFX D5), sulfamethazine-phenyl-13C6 (SMZ 13C6), and tetracycline-D6 (TC D6) with certified purity $(>95 \%)$ were manufactured by Toronto Research Chemicals (Toronto, ON, Canada).

Stock solutions of TC, 4-epi-TC, OTC, 4-epi-OTC, EFX, CFX, FLU, SCP, and SDZ were prepared in methanol at a concentration of $1000 \mu \mathrm{g} \mathrm{mL} \mathrm{m}^{-1}$ and stored at $-80^{\circ} \mathrm{C}$. Intermediate or working solutions were prepared using stock solutions diluted with methanol at a concentration of $1000 \mathrm{ng} \mathrm{mL}^{-1}$ which was stored at $-80^{\circ} \mathrm{C}$.

Mcllvaine-EDTA buffer $(0.1 \mathrm{M}, \mathrm{pH} 4.0 \pm 0.1)$, used for analyte extraction, was prepared by mixing $280 \mathrm{~mL}$ of solution A (14.2 g of hydrogen phosphate dihydrate in $500 \mathrm{~mL}$ of water), with $500 \mathrm{~mL}$ of solution B (10.5 g of citric acid monohydrate in $500 \mathrm{~mL}$ of water), then 74.4 $\mathrm{g}$ of EDTA was added. Milli- $\mathrm{Q}^{\circledR}$ water was added to a final volume of $2 \mathrm{~L}$. All other reagents, such as water, methanol, and acetonitrile were of analytical grade and were manufactured by Fisher (Thermo Fisher Scientific, Waltham, MA, USA) or Merck (Merck KGaA, Darmstadt, Germany). 


\subsection{Extraction of Antimicrobials}

Poultry litter samples were processed in a SKYMSEN ${ }^{\circledR}$ (Brusque, Brazil) grinder to homogenize the sample and reduce the size of the constituent.

For the analysis, $1 \pm 0.01 \mathrm{~g}$ of litter was placed in a $50 \mathrm{~mL}$ polypropylene tube and then spiked with different and equidistant analytes concentrations and internal standard described in Section 2.5. The extraction of analytes was carried out $15 \mathrm{~min}$ afterward. The samples were spiked with $8 \mathrm{~mL}$ of McIlvaine-EDTA buffer $(0.1 \mathrm{M}, \mathrm{pH} 4.0)$ and $2 \mathrm{~mL}$ of acetonitrile. The tube was then shaken, sonicated, and centrifuged in a Hettich ${ }^{\circledR}$ ROTOFIX 32A (Hettich Lab Technology, Beverly, MA, USA) at $2.700 \mathrm{~g}$ for $10 \mathrm{~min}$. The supernatants obtained were passed through Whatman ${ }^{\mathrm{TM}}$ filters grade GF/A $(1.6 \mu \mathrm{m})$ (Merck KGaA, Darmstadt, Germany) and transferred to another $50 \mathrm{~mL}$ polypropylene tube. Then, the samples were diluted by adding $13 \mathrm{~mL}$ of Mcllvaine-EDTA buffer and shaken and centrifuged for $5 \mathrm{~min}$ at $2700 \mathrm{~g}$. At the same time, solid-phase extraction columns SPE Supel ${ }^{\mathrm{TM}}$ Select HLB (Supelco, MERCK KGaA, Darmstadt, Germany) were conditioned with $5 \mathrm{~mL}$ of methanol and $5 \mathrm{~mL}$ of HPLC-grade water. Samples were passed through the columns, washed with $5 \mathrm{~mL}$ of HPLC-grade water, and dried with a manifold pump for $5 \mathrm{~min}$. The samples were eluted with $10 \mathrm{~mL}$ of methanol and evaporated under nitrogen flow in a water bath at $45 \pm 5^{\circ} \mathrm{C}$. The samples were reconstituted with $200 \mu \mathrm{L}$ of methanol and $300 \mu \mathrm{L}$ of HPLC-grade water and then shaken, sonicated, and centrifuged for $5 \mathrm{~min}$ at $2700 \mathrm{~g}$. The upper phase of the samples was transferred to Eppendorf microtubes, which were centrifuged in a VWR ${ }^{\circledR}$ 2417R (Avantor, Radnor, PA, USA) at 17,136 g for $10 \mathrm{~min}$. Finally, the supernatants were transferred through $33 \mathrm{~mm}$ Millex ${ }^{\circledR}$ filters (Merck KGaA, Burlington, MA, USA) into glass vials for subsequent analysis by HPLC-MS/MS.

\subsection{Instrument Analysis}

Samples were analyzed using an Agilent ${ }^{\circledR} 1290$ series liquid chromatograph (Agilent Technologies, Santa Clara, CA, USA), coupled with an ABSCIEX ${ }^{\circledR}$ API 5500 mass spectrometer (SCIEX, Framingham, MA, USA), and a SunfireTM C18 chromatographic column (Waters Corp., Milford, MA, USA) of $3.5 \mu \mathrm{m}$ and $150 \times 2.1 \mathrm{~mm}$ was used. The analytes were separated chromatographically using a mobile gradient of $0.1 \%$ formic acid in water (Phase A) and $0.1 \%$ formic acid in methanol (Phase B). The flow rate was adjusted to $0.2 \mathrm{~mL} / \mathrm{min}$, the injection volume was $20 \mu \mathrm{L}$, the duration was $25.423 \mathrm{~min}$, and the column temperature was set at $35^{\circ} \mathrm{C} \pm 1{ }^{\circ} \mathrm{C}$. The liquid chromatographic pump gradient is shown in Table 1. The scans per peak are shown in Table S1.

Table 1. Liquid chromatographic pump gradient.

\begin{tabular}{cccc}
\hline Total Time (min) & Flow Rate $(\mu \mathrm{L} / \mathbf{m i n})$ & A $(\mathbf{\%})$ & B $(\mathbf{\%})$ \\
\hline 0.00 & 200 & 85.0 & 15.0 \\
5.00 & 200 & 85.0 & 15.0 \\
5.10 & 200 & 60.0 & 40.0 \\
10.00 & 200 & 60.0 & 40.0 \\
10.10 & 200 & 10.0 & 90.0 \\
15.00 & 200 & 10.0 & 90.0 \\
16.00 & 200 & 85.0 & 15.0 \\
25.00 & 200 & 85.0 & 15.0 \\
\hline
\end{tabular}

The criteria to identify the different AMs and their active metabolites was the monitoring of the masses of the precursor and fragment ions (Table S2). In addition, different parameters were used for the operation of the mass detector (Table 2). The chromatographic integration of the samples was performed using Analyst ${ }^{\circledR}$ software version 1.6.2 (SCIEX, Framingham, MA, USA). 
Table 2. Operation parameters of the MS/MS detector.

\begin{tabular}{cc}
\hline Parameters & Analytical Conditions \\
\hline Ionization & Electrospray ionization (ESI) \\
Temperature & $550{ }^{\circ} \mathrm{C}$ \\
Curtain gas & $30 \mathrm{psi}$ \\
Collision gas & $10 \mathrm{psi}$ \\
Ion spray voltage & $4500 \mathrm{~V}$ \\
Ion source gas 1 & $60 \mathrm{psi}$ \\
Ion source gas 2 & $80 \mathrm{psi}$ \\
\hline
\end{tabular}

Samples were processed and analyzed at the Veterinary Pharmacology Laboratory (FARMAVET, as per initials in Spanish) of the Faculty of Veterinary and Animal Sciences at the University of Chile, which is accredited under ISO 17,025 standards.

\subsection{Method Validation Procedure}

To assure that the present method was suitable for detecting and quantifying AM residues in poultry litter, several performance parameters such as analyte retention time (RT), limit of detection (LOD), limit of quantification (LOQ), recovery, precision (through repeatability and intra-laboratory reproducibility) and linearity of the calibration curve were evaluated. For this purpose, an internal validation protocol was implemented that was designed following the recommendations provided by "European Community Commission Decision No. 657/2002" [43] and the VICH GL49 "Guidance for Industry" document regarding validation of analytical methods used in residue depletion studies [44].

For each AM, six pure drug replicates were analyzed to evaluate RT. For the determination of the detection range, a preliminary estimation of LOD and LOQ was performed to verify the existence of a linear relationship between concentration and instrument response. These values were determined as instrumental LOD and LOQ. Subsequently, the LOD and LOQ for each analyte were determined in a spiked matrix. The criteria for establishing the LOD was to achieve a signal-to-noise ratio greater than 3:1; while a signal-to-noise ratio higher than 10:1 was used to determine the LOQ. Repeatability was determined by analyzing six sets of samples spiked with either 25,50 , and $75 \mu \mathrm{g} \mathrm{kg}^{-1}$ on the same day. The intra-laboratory reproducibility was determined through the analysis of samples on different days and by a different analyst. Blank samples from poultry litter were analyzed to evaluate the specificity of the method. To determine the linearity of the calibration curve, spiked samples were analyzed at different and equidistant concentrations $(25,50,75$, and $100 \mu \mathrm{g} \mathrm{kg}^{-1}$ including zero). The matrix effect was evaluated comparing the response of the analyte in standard solution with its response in a spiked litter sample, all at the same concentration.

\subsection{Antimicrobial Monitoring in Commercial Flocks}

Litter samples from seven commercial flocks located in the Santiago Metropolitan Region, Chile, were collected. For each poultry farm pen, six replicates were obtained from different litter zones. The samples were stored at $-20{ }^{\circ} \mathrm{C}$ within labeled plastic bags until its subsequent processing, analyte extraction, and chromatographic analysis.

The quantification of AMs in poultry litters was performed using the equation of the line obtained from calibration curves in a matrix. The $\mathrm{R}^{2}$ considered was higher than 0.98 .

\section{Results}

\subsection{Implementation and Optimization of the Analytical Method}

The analytical method by Berendsen et al. [45] was optimized for the identification of AMs in poultry litter. The sample volume was reduced and extraction solvent volumes were increased. It was also necessary to filter through Whatman ${ }^{\mathrm{TM}}$ glass microfiber paper filters GF/A grade (1.6 $\mu \mathrm{m}$ ) (Merck KGaA, Darmstadt, Germany). The increase of solvent 
and addition of the paper filter was used to improve the cleanliness of the samples, reducing interference that could affect the chromatographic reading and analysis.

\subsection{Validation of the Analytical Method}

The analytical method developed in this research was validated, and the following results were obtained:

\subsubsection{Selectivity and Specificity.}

The RT of all analytes remained constant in the six analyses performed and exhibited a relative standard deviation (RSD) of less than $5 \%$. For the tetracycline family the average RT were 10.5, 4.9, 11.7, and 7.3 min for TC, 4-epi-TC, OTC, and 4-epi-OTC, respectively. For the quinolone family the average RT were 11.5, 11.1, and $16.9 \mathrm{~min}$ for EFX, CFX, and FLU, respectively. For the sulphonamide family the average RT was $13.7 \mathrm{~min}$ for SCP and $6.3 \mathrm{~min}$ for SDZ. Finally, the average RT for the I.S. were 11.5, 12.4, and $10.1 \mathrm{~min}$ for EFX D5, SMZ 13C6, and TC D6, respectively. A representative chromatogram of a blank poultry litter sample spiked at the target level is shown in Figure 2. To exclude the existence of RT interference specific to each analyte, 20 samples (certified as free of AM residues) were analyzed. The results showed that within the analyzed samples there were no signs of RT interference (Figure S1). The matrix effect was higher than zero occurring loss in response. To minimize this effect, we quantify with calibration curves in matrix.



Figure 2. Representative chromatograms of a blank poultry litter sample spiked with $75 \mu \mathrm{g} \mathrm{kg}{ }^{-1}$ of the antimicrobials.

\subsubsection{Detection Range}

The LOD and LOQ in spiked poultry litter are shown for each analyte in Table 3. For validation of these parameters, nine samples were spiked at $50 \mu \mathrm{g} \mathrm{kg}^{-1}$. The RSD determined from the analysis of these replicates was less than $25 \%$. The LOQ values were between 26.852 and $62.582 \mu \mathrm{g} \mathrm{kg}{ }^{-1}$ and complied with the minimum signal-to-noise ratio 
of 10:1. From these concentrations, experimental samples were reliably and accurately quantified. The instrumental LOD and LOQ are shown in Table S3.

Table 3. Linearity of calibration curves and detection ranges in poultry litter.

\begin{tabular}{|c|c|c|c|c|c|}
\hline Analyte & Linearity $\left(R^{2}\right)^{10}$ & $\mathrm{R}^{2} \mathrm{SD}^{11}$ & $\mathrm{R}^{2} \mathrm{RSD}^{12}$ & $\operatorname{LOD}^{13}\left(\mu \mathrm{g} \mathrm{kg}^{-1}\right)$ & $\mathrm{LOQ}^{14}\left(\mu \mathrm{g} \mathrm{kg}^{-1}\right)$ \\
\hline $\mathrm{TC}^{1}$ & 0.985 & 0.004 & 0.373 & 10.711 & 32.133 \\
\hline 4-ері-TC ${ }^{2}$ & 0.977 & 0.001 & 0.070 & 8.951 & 26.852 \\
\hline OTC $^{3}$ & 0.979 & 0.003 & 0.347 & 11.487 & 34.460 \\
\hline 4-epi-OTC ${ }^{4}$ & 0.977 & 0.002 & 0.179 & 9.379 & 28.138 \\
\hline EFX $^{5}$ & 0.986 & 0.003 & 0.331 & 13.626 & 40.879 \\
\hline $\mathrm{CFX}^{6}$ & 0.980 & 0.011 & 1.127 & 20.861 & 62.582 \\
\hline FLU $^{7}$ & 0.980 & 0.005 & 0.555 & 11.729 & 35.188 \\
\hline $\mathrm{SCP}^{8}$ & 0.982 & 0.006 & 0.561 & 9.191 & 27.574 \\
\hline $\mathrm{SDZ}^{9}$ & 0.977 & 0.011 & 1.171 & 11.705 & 35.116 \\
\hline
\end{tabular}

${ }^{1}$ TC: tetracycline; ${ }^{2}$ 4-epi-TC: 4-epimer-tetracycline; ${ }^{3}$ OTC: oxytetracycline; ${ }^{4}$ 4-epi-OTC: 4-epimer-oxytetracycline; ${ }^{5}$ EFX: enrofloxacin; ${ }^{6}$ CFX: ciprofloxacin; ${ }^{7}$ FLU: flumequine; ${ }^{8}$ SCP: sulfachloropyridazine; ${ }^{9}$ SDZ: sulfadiazine; ${ }^{10}$ average $\mathrm{R}^{2}$ : coefficient of determination of 3 calibration curves in matrix spiked with $25,50,75$, and $100 \mathrm{\mu g} \mathrm{kg}^{-1}$ of antimicrobials, including zero; ${ }^{11}$ standard deviation; ${ }^{12}$ relative standard deviation; ${ }^{13}$ limit of detection in matrix; ${ }^{14}$ limit of quantification in matrix.

\subsubsection{Linearity of Calibration Curves}

Different AM concentration levels $\left(25,50,75\right.$, and $\left.100 \mu \mathrm{g} \mathrm{kg}^{-1}\right)$ were used for the creation of the calibration curves. For all analytes, the coefficients of determination $\left(R^{2}\right)$ were higher than 0.98 (Table 3), and the RSD values were lower than $25 \%$. The linearity of the curve did not contain significant variations that could affect the robustness of the analytical result.

\subsubsection{Recovery and Precision}

Recovery rates were calculated for each analyte based on target samples that were spiked at 25,50 , and $75 \mu \mathrm{g} \mathrm{kg}^{-1}$. All analytes exhibited recovery rates ranging from 93 to $108 \%$. The precision of the HPLC-MS/MS method was measured by intra-laboratory reproducibility and repeatability. The RSD of the intra-laboratory reproducibility was lower than $25 \%$. The RSD for repeatability was less than those observed for intra-laboratory reproducibility (Table 4).

Table 4. Repeatability, intra-laboratory reproducibility, and antimicrobial recovery in poultry litter.

\begin{tabular}{|c|c|c|c|c|}
\hline Analyte & $\begin{array}{l}\text { Work Concentration } \\
\left(\mu \mathrm{kg}^{-1}\right)\end{array}$ & $\begin{array}{c}\text { Repeatability RSD } 10 \\
(\%)\end{array}$ & $\begin{array}{c}\text { Reproducibility RSD } \\
(\%)\end{array}$ & $\begin{array}{c}\text { Average Recovery } \\
(\%)\end{array}$ \\
\hline \multirow{3}{*}{$\mathrm{TC}^{1}$} & 25 & 1.78 & 5.17 & 94.6 \\
\hline & 50 & 1.69 & 4.64 & 105.4 \\
\hline & 75 & 0.58 & 1.66 & 98.2 \\
\hline \multirow{3}{*}{ 4-ері-TC ${ }^{2}$} & 25 & 2.51 & 9.85 & 91.7 \\
\hline & 50 & 2.82 & 8.34 & 108.3 \\
\hline & 75 & 0.87 & 3.10 & 97.2 \\
\hline \multirow{3}{*}{ OTC $^{3}$} & 25 & 3.94 & 6.38 & 92.4 \\
\hline & 50 & 3.72 & 5.48 & 107.6 \\
\hline & 75 & 1.29 & 2.01 & 97.5 \\
\hline \multirow{3}{*}{ 4-epi-OTC ${ }^{4}$} & 25 & 5.05 & 7.13 & 95.8 \\
\hline & 50 & 4.65 & 6.57 & 104.2 \\
\hline & 75 & 1.64 & 2.31 & 98.6 \\
\hline \multirow{3}{*}{$\mathrm{EFX}^{5}$} & 25 & 4.96 & 10.64 & 95.4 \\
\hline & 50 & 5.61 & 9.71 & 104.6 \\
\hline & 75 & 1.72 & 3.44 & 98.5 \\
\hline
\end{tabular}


Table 4. Cont.

\begin{tabular}{|c|c|c|c|c|}
\hline Analyte & $\begin{array}{c}\text { Work Concentration } \\
\left(\mu g \mathrm{~kg}^{-1}\right)\end{array}$ & $\begin{array}{c}\text { Repeatability RSD } \\
(\%)\end{array}$ & $\begin{array}{c}\text { Reproducibility RSD } \\
(\%)\end{array}$ & $\begin{array}{c}\text { Average Recovery } \\
(\%)\end{array}$ \\
\hline \multirow{3}{*}{$\mathrm{CFX}^{6}$} & 25 & 7.58 & 9.60 & 95.8 \\
\hline & 50 & 8.23 & 8.83 & 104.2 \\
\hline & 75 & 2.60 & 3.11 & 98.6 \\
\hline \multirow{3}{*}{ FLU $^{7}$} & 25 & 3.68 & 6.91 & 93.7 \\
\hline & 50 & 3.62 & 6.09 & 106.3 \\
\hline & 75 & 1.22 & 2.20 & 97.9 \\
\hline \multirow{3}{*}{$\mathrm{SCP}^{8}$} & 25 & 3.31 & 4.91 & 93.0 \\
\hline & 50 & 3.29 & 4.27 & 107.0 \\
\hline & 75 & 1.10 & 1.56 & 97.7 \\
\hline \multirow{3}{*}{$\mathrm{SDZ}^{9}$} & 25 & 1.59 & 10.01 & 95.6 \\
\hline & 50 & 1.92 & 9.17 & 104.4 \\
\hline & 75 & 0.56 & 3.24 & 98.5 \\
\hline
\end{tabular}

${ }^{1}$ TC: tetracycline; ${ }^{2}$ 4-epi-TC: 4 -epimer-tetracycline; ${ }^{3}$ OTC: oxytetracycline; ${ }^{4}$ 4-epi-OTC: 4-epimer-oxitetracycline; ${ }^{5}$ EFX: enrofloxacin;

${ }^{6}$ CFX: ciprofloxacin; ${ }^{7}$ FLU: flumequine; ${ }^{8}$ SCP: sulfachloropyridazine; ${ }^{9}$ SDZ: sulfadiazine; ${ }^{10}$ relative standard deviation.

\subsection{Analysis of Antimicrobial Concentrations in Commercial Flocks Litter}

The application of the analytical method for detection and quantification of veterinary pharmaceuticals in litter collected from poultry farms showed that AMs residues were present at means concentrations ranging from 20 to $10,364 \mu \mathrm{g} \mathrm{kg}^{-1}$. The AMs identified were EFX, CFX, SCP, OTC, and TC. In two out of seven poultry litter samples, no residues of any of the AMs studied were detected. The quantification of AMs is shown in Table 5.

Table 5. Antimicrobial residues in poultry litter samples from commercial poultry farms.

\begin{tabular}{|c|c|c|c|c|c|c|}
\hline $\begin{array}{c}\text { Poultry Litter } \\
\text { Sample }\end{array}$ & $\begin{array}{c}\mathrm{TC}^{1}+4 \text {-epi-TC } \\
\left(\mu \mathrm{g} \mathrm{kg}^{-1}\right)\end{array}$ & $\begin{array}{c}\text { OTC }^{3}+4 \text {-epi-OTC } \\
\left(\mu \mathrm{g} \mathrm{kg}^{-1}\right)\end{array}$ & $\begin{array}{c}\mathrm{EFX}^{5}+\mathrm{CFX}^{6} \\
\left(\mu \mathrm{g} \mathrm{kg} \mathrm{kg}^{-1}\right)\end{array}$ & $\begin{array}{c}\text { FLU }^{7} \\
\left(\mu \mathrm{kg}^{-1}\right)\end{array}$ & $\begin{array}{c}\mathrm{SCP}^{8} \\
\left(\mu \mathrm{g} \mathrm{kg}^{-1}\right)\end{array}$ & $\begin{array}{c}\mathrm{SDZ}^{9} \\
\left(\mu \mathrm{g} \mathrm{kg}^{-1}\right)\end{array}$ \\
\hline Farm 1 & nd & nd & $20.73 \pm 10^{10}$ & nd & nd & nd \\
\hline Farm 2 & nd & nd & nd & nd & nd & nd \\
\hline Farm 3 & nd & nd & nd & nd & $179.99 \pm 83$ & nd \\
\hline Farm 4 & nd & nd & $24,307.11 \pm 10$ & nd & nd & nd \\
\hline Farm 5 & nd & nd & nd & nd & nd & nd \\
\hline Farm 6 & nd & $66.43 \pm 53$ & nd & nd & nd & nd \\
\hline Farm 7 & $322.10 \pm 229$ & $10,364.41 \pm 6791$ & nd & nd & nd & nd \\
\hline
\end{tabular}

${ }^{1}$ TC: tetracycline; ${ }^{2}$ 4-epi-TC: 4-epimer-tetracycline; ${ }^{3}$ OTC: oxytetracycline; ${ }^{4}$ 4-epi-OTC: 4 -epimer-oxitetracycline; ${ }^{5}$ EFX: enrofloxacin;

${ }^{6}$ CFX: ciprofloxacin; ${ }^{7}$ FLU: flumequine; ${ }^{8}$ SCP: sulfachloropyridazine; ${ }^{9}$ SDZ: sulfadiazine; ${ }^{10}$ standard deviation; nd: not detected.

\section{Discussion}

Poultry droppings, through poultry litter, are commonly used to improve soil fertility worldwide. Using poultry litter is an economical way to dispose of the waste products generated in substantial quantities in the poultry industry [46]. Global poultry meat production increased from 9 to 122 million tons between 1961 and 2017 [47] and the amount of poultry litter generated by poultry in a production cycle of 42 days of life varies from 1.5 to $5.7 \mathrm{~kg}$ of litter per bird [12]. There is evidence indicating that poultry litter does not meet the minimum standards for application as organic fertilizer, mainly due to the presence of contaminants such as AM residues, pathogens, AM resistance genes, heavy metals, etc. Despite this, poultry litter continues to be used and there are no regulations regarding its use as agricultural fertilizer [21].

There is a growing concern for the presence of AM residues, and hence, the persistence and risks of these emerging contaminants have been investigated in both poultry droppings and litter [16,48-53]. The primary concern is the continuous pressure on bacteria resulting in the selection of microorganisms with genes encoding resistance to AMs [35]. Therefore, 
monitoring the use of AMs in both feed and poultry droppings has been described as a key strategy to control the emerging problem of AMs resistance [4].

The present research was aimed at developing a noninvasive, efficient, and effective method to sensitively and affordably monitor the presence of AMs in poultry litter prior to its use as an agricultural fertilizer. Although there was an important multiresidue method developed by Furtula et al. [15] to identify different residues of AMs by HLPCMS/MS in poultry litter, it was mainly limited to the detection of polyether ionophores (e.g., monensin, salinomycin, and narasin). Our method has the advantage of detecting different AMs belonging to the tetracyclines, sulphonamides, and quinolones families. These families of AMs are described by the OIE as some of the most used families worldwide in animals $[54,55]$ and are widely used in the poultry industry [4,5]. Moreover, unlike other methods [56], ours allows the simultaneous analysis of AMs in both their parent molecule and the metabolite forms (epimers or isomers) [9].

The multiresidual method developed by Berendsen et al. [45], which detects AMs in porcine and bovine feces, provides us the basis for this research. The present method, modified for poultry litter, was optimized by decreasing the gradient, using different solidphase extraction columns, increasing the solvents (Mcllvaine-EDTA buffer and acetonitrile), using microfiber paper filters, and adding additional steps such as the grinding of the raw sample to decrease the poultry litter diameter. These modifications improved the samples cleanup, which reduced the presence of impurities that could interfere with the chromatographic analysis. The optimized analytical method was able to detect and quantify the concentration of all analytes evaluated in poultry litter in a selective, accurate, and reliable manner. All parameters determined during the validation process of the HPLCMS/MS method comply with the acceptance criteria according to 657/2002/EC [43] and the VICH GL49 [44].

The analysis of samples obtained from commercial flocks confirmed the adequacy of this method. In this sense, high concentrations of EFX and OTC detected in litter samples may be associated with the use of these AMs, considering the number of pharmacological formulations registered for use in poultry [6]. The highest concentrations of AMs residues in field samples from poultry farms correspond to EFX. This is consistent with previous research performed in Brazil, which confirms EFX as the quinolone most often detected, and with the highest mean concentrations in poultry litters samples [16]. Results from commercial flocks show that antimicrobials used in poultry production might represent one potential source of dissemination of AMs residues into the environment. Accordingly, we developed a simple and affordable method for detecting and quantifying antimicrobials in poultry litter through HPLC-MS/MS. This can be considered to be a significant step forward for future AMs residues monitoring programs in this poultry by-product.

\section{Conclusions}

The analytical method developed for the simultaneous detection and quantification of AMs was validated to ensure the residues of tetracycline, 4-epi-tetracycline, oxytetracycline, 4-epi-oxytetracycline, enrofloxacin, ciprofloxacin, flumequine, sulfachloropyridazine, and sulfadiazine can be accurately and reliably detected in poultry litter. Additionally, the method developed here was successfully tested to detect and quantify antimicrobials residues in litter samples obtained from commercial flocks.

The method described could be employed as an affordable tool for monitoring and understanding the presence and persistence of antimicrobials in poultry litter. Effective monitoring can help to mitigate effects on human, animal, and environmental health that may arise from the use of antimicrobial agents.

Supplementary Materials: The following are available online at https: / www.mdpi.com/article / 10.3390/ani11051399/s1, Figure S1: Representative chromatograms from (1) a pure standard solution injection and (2) a blank poultry litter sample of (a) tetracycline, (b) 4-epimer-tetracycline, (c) oxytetracycline, (d) 4-epimer-oxytetracycline, (e) enrofloxacin, (f) ciprofloxacin, (g) flumequine, (h) sulfachloropyridazine, (i) sulfadiazine, Table S1: Scans per peak, Table S2: Mass of precursor and 
fragment ions, and specific mass spectrometry conditions, Table S3: Instrumental Limit of detection and Limit of quantification.

Author Contributions: Conceptualization K.Y. and J.C.; methodology, K.Y., E.P., and L.T.; software, A.M.; validation, K.Y., E.P., and L.T.; formal analysis E.P and A.M.; investigation, J.C.; resources, B.S.M.; data curation, E.P.; writing-original draft preparation, K.Y.; writing-review and editing, J.C., N.G., and L.L.; supervision, J.C., and H.H.; project administration, J.C.; funding acquisition, J.C. All authors have read and agreed to the published version of the manuscript.

Funding: This research was funded by Vicerrectoría de Investigación y Desarrollo (VID), grant number VID2019 ENL07/19, International Atomic Energy Agency (IAEA), grant number Research contract 22180 (D52041). The APC was funded by Vicerrectoría de Investigación y Desarrollo (VID), grant number VID2019 ENL07/19.

Institutional Review Board Statement: This research was performed in compliance with Law No. 20,380 "On the protection of animals," Directive 2010/63/EU on the protection of animals used for scientific purposes and regulations (EC) No. 1099/2009) on the protection of animals at the time of slaughter. In addition, it was approved by the institutional Committee for care and use of animal (CICUA) of the University of Chile (Certificate No.: 18187-VET-UCH-E1, approved on 5 July 2019)

Informed Consent Statement: Not applicable.

Data Availability Statement: The data presented in this research are available in the article and Supplementary Material.

Acknowledgments: The authors appreciate the collaboration of Andrés Flores and Constanza Casanova for the technical support.

Conflicts of Interest: The authors declare that there is no conflict of interest.

\section{References}

1. Yang, Y.; Ashworth, A.J.; Willett, C.; Cook, K.; Upadhyay, A.; Owens, P.R.; Ricke, S.C.; DeBruyn, J.M.; Moore, P.A., Jr. Review of Antibiotic Resistance, Ecology, Dissemination, and Mitigation in U.S. Broiler Poultry Systems. Front. Microbiol. 2019, 10, 2639. [CrossRef] [PubMed]

2. Food and Drug Administration. Food and Drug Administration Summary Report on Antimicrobials Sold or Distributed for Use in Food-Producing Animals; Food and Drug Administration, Department of Health and Human Services: Silver Spring, MD, USA, 2017 ; p. 67.

3. Van Boeckel, T.P.; Brower, C.; Gilbert, M.; Grenfell, B.T.; Levin, S.A.; Robinson, T.P.; Teillant, A.; Laxminarayan, R. Global Trends in Antimicrobial Use in Food Animals. Proc. Natl. Acad. Sci. USA 2015, 112, 5649-5654. [CrossRef] [PubMed]

4. Muhammad, J.; Khan, S.; Su, J.Q.; Hesham, A.E.-L.; Ditta, A.; Nawab, J.; Ali, A. Antibiotics in Poultry Manure and Their Associated Health Issues: A Systematic Review. J. Soils Sediments 2020, 20, 486-497. [CrossRef]

5. Roth, N.; Käsbohrer, A.; Mayrhofer, S.; Zitz, U.; Hofacre, C.; Domig, K.J. The Application of Antibiotics in Broiler Production and the Resulting Antibiotic Resistance in Escherichia Coli: A Global Overview. Poult. Sci. 2019, 98, 1791-1804. [CrossRef]

6. SAG, Servicio Agrícola y Ganadero. Lista de Medicamentos Veterinarios Autorizados Por El SAG. Available online: https: / / www2.sag.gob.cl/pecuaria/medicamentos/medicamentos_list.asp (accessed on 6 May 2020).

7. SAG, Servicio Agrícola y Ganadero. Declaración de Venta de Antimicrobianos. Available online: https://www.sag.gob.cl/ ambitos-de-accion/declaracion-de-venta-de-antimicrobianos (accessed on 6 May 2020).

8. Peng, P.; Wang, Y.; Liu, L.; Zou, Y.; Liao, X.; Liang, J.; Wu, Y. The Excretion and Environmental Effects of Amoxicillin, Ciprofloxacin, and Doxycycline Residues in Layer Chicken Manure. Poult. Sci. 2016, 95, 1033-1041. [CrossRef]

9. Massé, D.; Saady, N.; Gilbert, Y. Potential of Biological Processes to Eliminate Antibiotics in Livestock Manure: An Overview. Animals 2014, 4, 146-163. [CrossRef]

10. Mehdi, Y.; Létourneau-Montminy, M.-P.; Gaucher, M.-L.; Chorfi, Y.; Suresh, G.; Rouissi, T.; Brar, S.K.; Côté, C.; Ramirez, A.A.; Godbout, S. Use of Antibiotics in Broiler Production: Global Impacts and Alternatives. Anim. Nutr. 2018, 4, 170-178. [CrossRef]

11. Herath, E.M.; Palansooriya, A.G.K.N.; Dandeniya, W.S.; Jinadasa, R.N. An Assessment of Antibiotic Resistant Bacteria in Poultry Litter and Agricultural Soils in Kandy District, Sri Lanka. Trop. Agric. Res. 2016, 27, 389. [CrossRef]

12. Santos Dalólio, F.; da Silva, J.N.; Carneiro de Oliveira, A.C.; de Ferreira Tinôco, I.F.; Christiam Barbosa, R.; de Resende, M.O.; Teixeira Albino, L.F.; Teixeira Coelho, S. Poultry Litter as Biomass Energy: A Review and Future Perspectives. Renew. Sustain. Energy Rev. 2017, 76, 941-949. [CrossRef]

13. Cornejo, J.; Pokrant, E.; Krogh, M.; Briceño, C.; Hidalgo, H.; Maddaleno, A.; Araya-Jordán, C.; San Martín, B. Determination of Oxytetracycline and 4-Epi-Oxytetracycline Residues in Feathers and Edible Tissues of Broiler Chickens Using Liquid Chromatography Coupled with Tandem Mass Spectrometry. J. Food Prot. 2017, 80, 619-625. [CrossRef] 
14. Pokrant, E.; Medina, F.; Maddaleno, A.; San Martín, B.; Cornejo, J. Determination of Sulfachloropyridazine Residue Levels in Feathers from Broiler Chickens after Oral Administration Using Liquid Chromatography Coupled to Tandem Mass Spectrometry. PLoS ONE 2018, 13, e0200206. [CrossRef]

15. Furtula, V.; Huang, L.; Chambers, P.A. Determination of Veterinary Pharmaceuticals in Poultry Litter and Soil by Methanol Extraction and Liquid Chromatography-Tandem Mass Spectrometry. J. Environ. Sci. Health B 2009, 44, 717-723. [CrossRef]

16. Leal, R.M.P.; Figueira, R.F.; Tornisielo, V.L.; Regitano, J.B. Occurrence and Sorption of Fluoroquinolones in Poultry Litters and Soils from São Paulo State, Brazil. Sci. Total Environ. 2012, 432, 344-349. [CrossRef]

17. Van Epps, A.; Blaney, L. Antibiotic Residues in Animal Waste: Occurrence and Degradation in Conventional Agricultural Waste Management Practices. Curr. Pollut. Rep. 2016, 2, 135-155. [CrossRef]

18. Codex Alimentarius Maximum Residue Limits (MRLs) and Risk Management Recommendations (RMRs) for Residues of Veterinary Drugs in Foods CX/MRL 2-2018. 2018. Available online: http:/ /www.fao.org/fao-who-codexalimentarius/sh-proxy/ en / ?lnk=1\&url=https $\% 253 \mathrm{~A} \% 252 \mathrm{~F} \% 252 \mathrm{Fw}$ orkspace.fao.org\%252Fsites $\% 252 \mathrm{~F}$ codex $\% 252 \mathrm{FStandards} \% 252 \mathrm{FCXM} \% 2 \mathrm{~B} 2 \% 252$ FMRL2e.pdf (accessed on 24 November 2020).

19. Marble, S.C.; Sibley, J.L.; Gilliam, C.H.; Torbert, H.A. Application of Composted Poultry Litter as a Fertilizer for Landscape Bedding Plants. HortScience 2011, 46, 1367-1372. [CrossRef]

20. Tewolde, H.; Sistani, K.R.; Adeli, A. Fall- and Spring-Applied Poultry Litter Effectiveness as Corn Fertilizer in the Mid-Southern United States. Agron. J. 2013, 105, 1743-1748. [CrossRef]

21. Kyakuwaire, M.; Olupot, G.; Amoding, A.; Nkedi-Kizza, P.; Ateenyi Basamba, T. How Safe Is Chicken Litter for Land Application as an Organic Fertilizer? A Review. Int. J. Environ. Res. Public Health 2019, 16, 3521. [CrossRef]

22. Hedman, H.D.; Vasco, K.A.; Zhang, L. A Review of Antimicrobial Resistance in Poultry Farming within Low-Resource Settings. Animals 2020, 10, 1264. [CrossRef]

23. Manyi-Loh, C.; Mamphweli, S.; Meyer, E.; Okoh, A. Antibiotic Use in Agriculture and Its Consequential Resistance in Environmental Sources: Potential Public Health Implications. Molecules 2018, 23, 795. [CrossRef]

24. Zhang, H.; Zhou, Y.; Huang, Y.; Wu, L.; Liu, X.; Luo, Y. Residues and Risks of Veterinary Antibiotics in Protected Vegetable Soils Following Application of Different Manures. Chemosphere 2016, 152, 229-237. [CrossRef]

25. Wei, R.; Ge, F.; Zhang, L.; Hou, X.; Cao, Y.; Gong, L.; Chen, M.; Wang, R.; Bao, E. Occurrence of 13 Veterinary Drugs in Animal Manure-Amended Soils in Eastern China. Chemosphere 2016, 144, 2377-2383. [CrossRef] [PubMed]

26. Hou, J.; Wan, W.; Mao, D.; Wang, C.; Mu, Q.; Qin, S.; Luo, Y. Occurrence and Distribution of Sulfonamides, Tetracyclines, Quinolones, Macrolides, and Nitrofurans in Livestock Manure and Amended Soils of Northern China. Environ. Sci. Pollut. Re.s 2015, 22, 4545-4554. [CrossRef] [PubMed]

27. Cycoń, M.; Mrozik, A.; Piotrowska-Seget, Z. Antibiotics in the Soil Environment-Degradation and Their Impact on Microbial Activity and Diversity. Front. Microbiol. 2019, 10, 338. [CrossRef] [PubMed]

28. Minden, V.; Deloy, A.; Volkert, A.M.; Leonhardt, S.D.; Pufal, G. Antibiotics Impact Plant Traits, Even at Small Concentrations. Aob Plants 2017, 9. [CrossRef]

29. Jafari Ozumchelouei, E.; Hamidian, A.H.; Zhang, Y.; Yang, M. Physicochemical Properties of Antibiotics: A Review with an Emphasis on Detection in the Aquatic Environment. Water Environ. Res. 2020, 92, 177-188. [CrossRef]

30. Grenni, P.; Ancona, V.; Barra Caracciolo, A. Ecological Effects of Antibiotics on Natural Ecosystems: A Review. Microchem. J. 2018, 136, 25-39. [CrossRef]

31. Kumar, K.; Gupta, S.C.; Baidoo, S.K.; Chander, Y.; Rosen, C.J. Antibiotic Uptake by Plants from Soil Fertilized with Animal Manure. J. Environ. Qual. 2005, 34, 2082-2085. [CrossRef]

32. American College of Allergy, Asthma and Immunology (ACAAI). Allergic Reaction to Antibiotic Residues in Foods? You May Have to Watch What Your Fruits and Veggies Eat. 2014. Available online: https:/ /acaai.org/news/you-may-have-watch-whatyour-fruits-and-veggies-eat (accessed on 12 August 2020).

33. Blaser, M.J. Antibiotic Use and Its Consequences for the Normal Microbiome. Science 2016, 352, 544-545. [CrossRef]

34. Palma, E.; Tilocca, B.; Roncada, P. Antimicrobial Resistance in Veterinary Medicine: An Overview. Int. J. Mol. Sci. 2020, $21,1914$. [CrossRef]

35. Ben, Y.; Fu, C.; Hu, M.; Liu, L.; Wong, M.H.; Zheng, C. Human Health Risk Assessment of Antibiotic Resistance Associated with Antibiotic Residues in the Environment: A Review. Environ. Res. 2019, 169, 483-493. [CrossRef]

36. Hu, X.-G.; Yi, L.; Zhou, Q.-X.; Xu, L. Determination of Thirteen Antibiotics Residues in Manure by Solid Phase Extraction and High Performance Liquid Chromatography. Chin. J. Anal. Chem. 2008, 36, 1162-1166. [CrossRef]

37. Feng, Y.; Zhang, W.-J.; Liu, Y.-W.; Xue, J.-M.; Zhang, S.-Q.; Li, Z.-J. A Simple, Sensitive, and Reliable Method for the Simultaneous Determination of Multiple Antibiotics in Vegetables through SPE-HPLC-MS/MS. Molecules 2018, 23, 1953. [CrossRef]

38. Rashid, A.; Mazhar, S.H.; Zeng, Q.; Kiki, C.; Yu, C.-P.; Sun, Q. Simultaneous Analysis of Multiclass Antibiotic Residues in Complex Environmental Matrices by Liquid Chromatography with Tandem Quadrupole Mass Spectrometry. J. Chromatogr. B 2020, 1145, 122103. [CrossRef]

39. US Department of Agriculture (USDA). Poultry Industry Manual. 2013. Available online: https://www.aphis.usda.gov/animal_ health/emergency_management/downloads/documents_manuals/poultry_ind_manual.pdf (accessed on 9 August 2020).

40. Congreso Nacional de la República de Chile Ley N²0.380 Sobre la Protección de los Animales. 2017. Available online: https:/ / www.bcn.cl/leychile/navegar?idNorma=1006858 (accessed on 28 November 2020). 
41. European Parliament. European Parliament and the Council of the European Union Directive 2010/63/EU of 22 September 2010 of the European Parliament and of the Council on the Protection of Animals Used for Scientific Purposes. Off. J. Eur. Union 2018, 276, 33-79.

42. European Parliament and the Council of the European Union COUNCIL REGULATION (EC) No 1099/2009 of 24 September 2009 on the Protection of Animals at the Time of Killing. 2009. Available online: https: / / eur-lex.europa.eu/LexUriServ/LexUriServ. do?uri=OJ:L:2009:303:0001:0030:EN:PDF (accessed on 10 October 2020).

43. European Commission 2002/657/EC: Commission Decision of 12 August 2002 Implementing Council Directive 96/23/EC Concerning the Performance of Analytical Methods and the Interpretation of Results. 2002. Available online: https:/ / eur-lex. europa.eu/LexUriServ /LexUriServ.do?uri=OJ:L:2002:221:0008:0036:EN:PDF (accessed on 17 October 2020).

44. GL49: Studies to Evaluate the Metabolism and Residues Kinetics of Veterinary Drugs in Human Food-Producing Animals: Validation of Analytical Methods Used in Residue Depletion Studies. Available online: https://www.ema.europa.eu/en/ documents/scientific-guideline/vich-g149-studies-evaluate-metabolism-residue-kinetics-veterinary-drugs-food-producinganimals_en.pdf (accessed on 13 December 2020).

45. Berendsen, B.J.A.; Wegh, R.S.; Memelink, J.; Zuidema, T.; Stolker, L.A.M. The Analysis of Animal Faeces as a Tool to Monitor Antibiotic Usage. Talanta 2015, 132, 258-268. [CrossRef]

46. Chojnacka, K.; Moustakas, K.; Witek-Krowiak, A. Bio-Based Fertilizers: A Practical Approach towards Circular Economy. Bioresour. Technol. 2020, 295, 122223. [CrossRef]

47. Organizacion de las Naciones Unidas para la Alimentacion y la Agricultura Producción y Productos Avícolas. Available online: http:/ / www.fao.org/poultry-production-products/production/es / (accessed on 8 January 2021).

48. Bolan, N.S.; Szogi, A.A.; Chuasavathi, T.; Seshadri, B.; Rothrock, M.J.; Panneerselvam, P. Uses and Management of Poultry Litter. World's Poult. Sci. J. 2010, 66, 673-698. [CrossRef]

49. Albero, B.; Tadeo, J.L.; Escario, M.; Miguel, E.; Pérez, R.A. Persistence and Availability of Veterinary Antibiotics in Soil and Soil-Manure Systems. Sci. Total Environ. 2018, 643, 1562-1570. [CrossRef]

50. Berendsen, B.J.A.; Lahr, J.; Nibbeling, C.; Jansen, L.J.M.; Bongers, I.E.A.; Wipfler, E.L.; van de Schans, M.G.M. The Persistence of a Broad Range of Antibiotics during Calve, Pig and Broiler Manure Storage. Chemosphere 2018, 204, 267-276. [CrossRef]

51. Cornejo, J.; Yevenes, K.; Avello, C.; Pokrant, E.; Maddaleno, A.; Martin, B.; Lapierre, L. Determination of Chlortetracycline Residues, Antimicrobial Activity and Presence of Resistance Genes in Droppings of Experimentally Treated Broiler Chickens. Molecules 2018, 23, 1264. [CrossRef]

52. Yévenes, K.; Pokrant, E.; Pérez, F.; Riquelme, R.; Avello, C.; Maddaleno, A.; Martín, B.S.; Cornejo, J. Assessment of Three Antimicrobial Residue Concentrations in Broiler Chicken Droppings as a Potential Risk Factor for Public Health and Environment. Int. J. Environ. Res. Public Health 2018, 16, 24. [CrossRef]

53. Manikandan, M.; Chun, S.; Kazibwe, Z.; Gopal, J.; Singh, U.B.; Oh, J.-W. Phenomenal Bombardment of Antibiotic in Poultry: Contemplating the Environmental Repercussions. Int. J. Environ. Res. Public Health 2020, 17, 5053. [CrossRef]

54. Organizacion Mundial de Sanidad Animal. Informe Anual de La OIE Sobre El Uso de Agentes Antimicrobianos En Los Animales: Comprendiendo Mejor La Situacion Mundial; OIE: Paris, France, 2016.

55. World Organisation for Animal Health OIE. Annual Report on Antimicrobial Agents Intended for Use in Animals; OIE: Paris, France, 2018.

56. Paranhos, A.G.O.; Pereira, A.R.; da Fonseca, I.C.; Sanson, A.L.; Afonso, R.J.C.F.; Aquino, S.F. Analysis of Tylosin in Poultry Litter by HPLC-UV and HPLC-MS/MS after LTPE. Int. J. Environ. Anal. Chem. 2020, 1-18. [CrossRef] 